\title{
THE IMPACT OF EXPLOITATION ON RESOURCE UTILIZATION AND GOAL FOCUS IN TELECOMMUNICATION INDUSTRY
}

\author{
${ }^{1}$ Oloda Oluwatayo Felix \& ${ }^{2}$ Prof. B. C. Onuoha \\ 1,2 Department of Management University of Port Harcourt
}

\begin{abstract}
This study examined the relationship between exploitation, resource utilization and goal focus in telecommunication industry. The sample for this study consisted of 84 management staff from the four leading Telecommunication giants (MTN, Globacom, Airtel and 9 Mobile). The data for this research was collected using the questionnaire method. The Kendall Tau statistical tool was used to test the relationships between the variables under review. The findings reveal a significant positive relationship between Exploitation and both Resource utilization and Goal focus. It was concluded based on our statistical analysis that organizational exploitation enhances corporate health. More specifically, it was concluded that exploitation enhances resource utilization and goal focus. In view of these results and conclusions above, this study recommends that; Managers should acknowledge the importance of exploration in fostering a better resource utilization which will bring about a healthy organization. Employee involvement, especially employees that are opened to change should be encouraged at all organization level.
\end{abstract}

Keywords: Exploitation, Resource utilization, goal focus, health, organization 


\section{Introduction}

Ambidexterity has been defined as the ability of organization to balance short and long-term goals. Given that this is the capability to keep up a balance between research and operational processes, the most important result of ambidexterity is innovation, since innovation requires both research and operational aspects. Innovation is described as "the sequence of actions by which a new element is introduced into a social unit to benefit the unit, a part of it or society in general" (West and Farr, 1990). The new element need not be entirely novel or unfamiliar to members of the unit, but it must involve some discernible change or challenge to the current parameters (West \& Farr, 1990). Most theoretical models of innovation differentiate at least two processes: idea generation and idea implementation (e.g., Amabile, 1988; West, 2002). The generation phase is directly related to research activities, and the implementation phase is kinly related to operational activities. A two-sided organization is capable of introducing innovations (creating new products / services), while maintaining constant use of proven methods / products.

Furthermore, ambition can contribute to other positive organizational outcomes in addition to innovation. The literature has shown that the interface between research and operational innovation strategies (in other words, ambidextrous) is positively related to the growth in sales rates, and the imbalance between research and operational innovation strategies is adversely associated to sales growth rates (He \& Wong, 2004). Several organizations have been able to overcome organizational challenges and be more innovative due to ambiguity. A study carried out in 41 companies showed that ambidexterity is closely connected to efficiency. Similarly, another study of 34 high-tech organizations showed that their ability to simultaneously perform exploration and operation was associated with higher performance (Chandrasekaran et al. 2012).

Therefore, to achieve ambition, the organization's task is to organize a set of processes and systems that allow it, so also to encourage the organization' members to act ambitiously at their own discretion. This stream of research generally considers contextual strand, such as connectivity, trust, relaxation, discipline, and support, as the most influential.

Although scientists seek to study the prerequisites for organizational ambidexterity, the empirical results do not fully support the ambidexterity hypothesis in the strategy literature. Some studies have shown that companies that pursue different strategies in same vein may not produce better results than those that concentrate on any strategy (Ebben and Johnson, 2005; Ghemawat and Costa, 1993; Porter, 1980) in this work, we maintain that to actualize organizational ambidexterity; some contingent conditions must be met. To be more specific, both external and internal conditions must fit to make the organizations perform better. In the following sections, we first explicate the dimensions of organizational ambidexterity. Then we try to find out the factors affecting organizations to be ambidextrous.

Though organizational ambidexterity embodied on many organizational aspects, such as alignment and goal focus (Gibson et al., 2004), evolutionary and revolutionary change (Tushman, O'Reilly, \& Anderson, 2004), flexibility and efficiency (Adler et al., 1999; Ebben\& Johnson, 2005), this paper focuses on aspects related to corporate health. We are concerned in corporate health in that capabilities of innovation have been regarded as main sources of competitive advantages (Grant, 1996; Marsh \& Stock, 2006). In addition, through 
innovation, organizations develop and adjust to the changing environment (Nelson \& Winter, 1982).

Organizations adapt to the changing environment by utilizing their existing technology or knowledge and also by creating new ones (Teece, Pisano, \&Shuen, 1997). In the following segment, we discuss different kinds of innovation and the connection between organizational ambidexterity.

It is a common practice for people to care less about their health until they develop symptoms of illness. This attitude is replicated at the level of organizational where management gives less attention to the health status of an organization a situation where no one pays attention to organization management, methods of doing business, policies and practices until a warning is received. Top management does not imbibe the habit of constantly measuring the health status of the organization until the organizational develops symptoms of illness or even become sick. However, in order to avoid such situations and achieve as well as sustain a healthy organization, management should maintain activities that will promote a healthy organization structure through appropriate organizational health policies. According to Ardiç and Polatci (2007), from the time an organization is established appropriate measures should be put in place that will guard against the problems that may occur, and organization health should be measured periodically.

Measuring the health of the organizations goes beyond revealing how healthy an organization is, but to also put in place appropriate measures that guarantee improvement for the organization in tandem with the result obtained. The fact that an organization is seen as healthy or unhealthy indicates the need for change and innovation. Determining the causes of an unhealthy organizational structure is essential. In summary, measurements establish a conceptual framework in identifying and solving problems. Organizational strengths and weaknesses, as well as threats and opportunities are shown through paradigm of organization health.

Thus, it is strived to derive more resources from the strengths, and to improve and strengthen the weaknesses (Polatci et al., 2008).

\section{Research Hypotheses}

$\mathbf{H O}_{1}$ : There is no significant relationship between exploitation and resource utilization in the Nigerian telecommunication sector

$\mathbf{H O}_{2}$ : There is no significant relationship between exploitation and goal focus in the Nigerian telecommunication sector

\section{Theoretical Framework}

March's model of organizational learning theory shall be examined under this heading.

\section{Mental Models}

OL is grounded in work on mental models. LanganFox, Anglim, and Wilson (2004) defined mental models as internal (mental) representations of objects, actions, situations or people, and are built on experience and observation, of both the world in general and the particular 
entity of interest. This is similar to Argyris and Shon's (1996) notion of theory in use, "which is an inner characterization of actions, values, and embedded assumptions constructed from observing patterns of action. Huber and Lewis (2010) define mental model as a person's mental picture of a system and how it work. This definition includes (1) the variables included in the system, (2) the properties and states of those variables, and (3) the causal or other relationships among those variables\| (Huber \& Lewis, 2010). Chermack (2007) noted three phases of an effective and efficient organizational learning process as (1) mapping mental models, (2) challenging mental models, and (3) improving mental models\|.

Mental models shape managerial perceptions of their environment and enable sense making in complex situations (Johnson \& Huff, 1998). This in turn affects development and use of EE strategies (Atuahene Gima, 2005).

\section{Methodology}

The population of this study consists of all Telecommunication firms registered with the Nigerian Communication Commission (NCC). However, this study only focused on the four major and visible firms that have national coverage namely MTN, Airetel, Globacom and 9mobile with a population of 190. A sample size of 129 was gotten using Taro Yamene formula. To empirically evaluate the relationships between organizational ambidexterity and corporate health in Nigerian telecommunication firms, data obtained with the aid of questionnaire was analyzed using the Kendall's Tau correlation Coefficient statistical technique. The test requires that the responses be at least ordinal level. That is, the response can be ranked from high to low. This statistical tool is considered appropriate as the variables in this study were measured in ordinal scales.

Table 1: Correlations between exploitation, resource utilization and goal focus

\begin{tabular}{|lll|r|r|r|}
\hline & & & $\begin{array}{c}\text { Exploitatio } \\
\mathrm{n}\end{array}$ & $\begin{array}{c}\text { Resource } \\
\text { Utilisation }\end{array}$ & \multicolumn{1}{c|}{$\begin{array}{c}\text { Goal } \\
\text { Focus }\end{array}$} \\
\hline & & Correlation & 1.000 & $.446^{* * *}$ & $.450^{* * *}$ \\
& Exploitation & Coefficient & & \\
& & Sig. (2-tailed) & .002 & .000 \\
& $\mathrm{~N}$ & 84 & 84 & 84 \\
Kendall's & Correlation & $.446^{* *}$ & 1.000 & $.491^{* *}$ \\
tau_b & Resource & Coefficient & & \\
& Utilisation & Sig. (2-tailed) & .002 & .000 \\
& & $\mathrm{~N}$ & 84 & 84 & 84 \\
& & Correlation & $.450^{* * *}$ & $.491^{* *}$ & 1.000 \\
& & Coefficient & .000 & .000 &. \\
& Goal Focus & Sig. (2-tailed) & 84 & 84 & 84 \\
\hline
\end{tabular}

**. Correlation is significant at the 0.01 level (2-tailed).

Table 1 revealed the correlations between exploitation and resource utilization, and exploration and goal focus. The output showed moderate positive relationships between the variables. Specifically, there was a moderate positive relationship between exploitation and resource utilisation (tau_b $=.446, \mathrm{n}=84, \mathrm{P}<.01$ ), while the relationship between exploration 
and goal focus was also moderately positive (tau_b $=.450, \mathrm{n}=84, \mathrm{P}<.01$ ). These results imply that, the higher the exploitation among the firms, the higher they achieve resource utilization and goal focus. Based on these results, the null hypotheses were rejected and the alternative hypotheses accepted.

Results in table 1 showed the correlations between exploitation and the measures of corporate health (resource utilization and goal focus) of the organizations. The output indicated positive but moderate relationships between the variables.

This outcome implies that an increase in exploitation leads to an increase in resource utilization and goal focus in telecommunication firms. Based on this conclusion, hypotheses 1 and 2 were rejected.

Therefore, it was concluded that:

i. Exploitation is positively and moderately correlated with resource utilization and goal focus of the telecommunication firms.

ii. Also, an increase in exploitation leads to increase in resource utilization and goal focus of the telecommunication firms.

\section{Conclusion}

Empirical evidence here revealed a positive and moderate relationship between exploitation and resource utilization. Although no study in time past has linked exploitation with resource utilization. This revelation signifies that ambidexterity can bring about efficient and effective use of organizational resources, which will in turn predict sound organizational health. Given the fact that when an organization is healthy, employees are committed, responsible and beneficial and have high spirit and performance, A healthy organization is a wealthy organization where people come to their work enthusiastically and are proud of working in that place. In fact, the health of the organization in terms of physical and mental dimensions, safety, attachment, meritocracy and valuing knowledge, expertise, personality of beneficiaries, and developing their capabilities and performing the duties by their metasystems have a significant effect on effectiveness of behaviour of each system (Jahed, 2006).

A healthy organization is where the organization possesses the ability to detect failures in existing processes and prevent the repetition of these failures in the future by preparing action plans necessary for the success of the firm. The firm also has the ability to solve new problems that are not covered by the action plans; to perceive threats and opportunities in a timely manner and take proactive action; to create knowledge, experience, and lessons learned from exploratory activities for the success of the overall organization.

Empirical evidence on the relationship between exploitation and goal focus shows a positive and significant relationship between the two variables. Previous studies even acknowledged the importance of organizational ambidexterity as a factor for organizational performance and survival, but there is no empirical evidence showing a relationship exploitation and goal focus, this result is therefore very significant as it reveals that when organization exploit future opportunities such organizations become healthy in the sense that they will pursue clear cut goals and her employees will have a sense of direction. More so, higher level of exploitation leads to higher level of goal focus, that is, an increase in exploitation results in an increase in goal focus among the telecommunication firms. 


\section{Recommendations}

(i) Management should give full support to exploitative activities within the organization since exploitation enhances resource utilization. Partnering up with competitors, customers, as well as suppliers is very important. There should be sound and robust communication channels as these will foster healthy relationship among organizational members as well as accentuate the importance of cooperation across organizational boundaries as a way of hasting the process of a healthy organization.

(ii) Members of the organization should be well motivated as they drive organizational policy on exploiting future opportunities.

(iii) Lastly, initiating the right organizational structure that will pave way for exploitative activities should be paramount in the minds of decision makers in the organization. A flexible organizational structure will promote exploratory and exploitative activities which will bring about a healthy organization. 


\section{Bibliography}

Abernathy, W. J. - Clark, K. B. (1985): Innovation: Mapping the winds of creative destruction. Research Policy, (14): p. 3-22.

Abernathy, W.J., K. Clark 1985, Mapping the Winds of Creative Destruction. Research Policy 14 3-22.

Adelowo, W. B. (2014). Labour commitment and firm's productivity in Nigeria: A case study of Global Soap and Detergent Industries Limited, Ilorin, Kwara State. IOSR Journal of Agriculture and Veterinary Science (IOSR-JAVS), 7(5), 1-8.

Adelowo, W. B. (2014). Labour commitment and firm's productivity in Nigeria: A case study of Global Soap and Detergent Industries Limited, Ilorin, Kwara State. IOSR Journal of Agriculture and Veterinary Science (IOSR-JAVS), 7(5), 1-8.

Adler P.S, Goldoftas B., and Levine (1999).Flexibility vs. Efficiency?A case study of model changeovers in the Toyota production system. Organization Science. 10: 43-68.

Adler, P. S, Goldoftas, B., \& Levine, D. I. 1999.Flexibility versus efficiency?A case study of model changeovers in the Toyota production system.Organization35 Science, 10(1): 43.

Adler, P. S. - Goldoftas, B. - Levine, D. I. (1999): Flexibility versus efficiency: A case study of model changeovers in the Toyota production system. Organization Science, 10: p. 43-68.

Ahuja, G. - Lampert, C. (2001): Entrepreneurship in the large corporation: A longitudinal study of how established firms create breakthrough inventions. Strategic Management Journal, (22): p. 521-543.

Ahuja, G. \&Katila.K. (2004). Where do resources come from? The role of Idiosyncratic situations, strategic management journal, 25, 887-543.

Ahuja, G. and Lampert, C.M. 2001. Entrepreneurship in the Large Corporation: A Longitudinal Study of how established firms create breakthrough inventions. Strategic Management Journal, 22: 521-543.

Akgun, A. E., Lynn, G. S., \& Byrne, J. C. (2003). Organizational learning: A socio cognitive framework. Human Relations, 56(7), 839-868.

Anand, J., Mesquita, L. F., \&Vassolo, R. S. (2009). The dynamics of multimarket competition in exploration and exploitation activities. Academy of Management Journal, 52(4), 802-821.

Ancona, D. G. - Goodman, P. S. - Lawrence, B. S. - Tushman, M. L. (2001): Time: A new research lens. Academy of Management Review, (26): p. 645-663.

Ancona, D. G., P. S. Goodman, B. S. Lawrence, M. L. Tushman. 2001. Time: A new research lens. Acad. Management Rev. 26 645-663. 
Andriopoulos, C., \& Lewis, M. W. (2009).Exploitation-exploration tensions and organizational ambidexterity: Managing paradoxes of innovation. Organization Science, 20(4), 696-717.

Argote, L. (1999). Organizational learning.New York: Springer.

Argyris, C. - Schön, D. (1978): Organizational learning: A theory of action perspective. Reading, MA: Addison- Wesley.

Argyris, C., \&Shon, D. A. (1996).Organizational learning II.

AtuaheneGima, K. (2005). Resolving the capability rigidity paradox in new product innovation. Journal of Marketing, 69(4), 61-83.

Amin, S. (1999).Young women's experiences in the labor market in developing countries. Conference on Labor Market and Human Resource Development in Egypt, Economic Policy Initiative Consortium (EPIC) and Center for the Study of Developing Countries, Faculty of Economics and political Science, Cairo University, Cairo.

Amin, S. (1999).Young women's experiences in the labor market in developing countries. Conference on Labor Market and Human Resource Development in Egypt, Economic Policy Initiative Consortium (EPIC) and Center for the Study of Developing Countries, Faculty of Economics and political Science, Cairo University, Cairo.

Arppe, A. (2008). Bivariate, bivariate and multivariate methods in corpus-based lexicography.A study of synonymy. Helsinki: University of Helsinki.

Baayen, R. H. (2014). Multivariate statistics. Canada: University of Alberta, Edmonton.

Bagozzi, R. P. \& Yi, Y. (1988).On the evaluation of structural equations models. Journal of Academy of Marketing Science, 16(1), 74-94.

Baruch, Y. \&Holtom, B. C. (2008).Survey response rate levels and trends in organizational research.Human Relations, 61(8), 1139-1160.

Bazeley, P. (2009). Analysing qualitative data: More than 'identifying themes'. Malaysian J. Qualitative Res., 2, 6-22.

Bakka, J.F., Fivelsdal, E., \&Lindkvist, L. (2001) Organisational structure, culture, processer.(4th ed.) Malmö; Liber Ekonomi.

Balu, P.M and Schoenherr, R.A (1980) The Structure of Organisations. Basics Books, New York.

Benner, M. J. and Tushman, M. L. (2003), Exploitation, Exploration, and Process Management: The Productivity Dilemma Revisited, Academy of Management Review, 28 , pp. 238-256. 
Benner, M. J. and Tushman, M. L. (2003), Exploitation, Exploration, and Process Management: The Productivity Dilemma Revisited, Academy of Management Review, 28, pp. 238-256.

Benner, M. J., \&Tushman, M. (2002), Process management and technological innovation: A longitudinal study of the photography and paint industries. Administrative Science Quarterly, 47, 676-707.

Benner, M. J., \&Tushman, M. L. (2002). Process management and technological innovation: A longitudinal study of the photography and paint industries. Administrative Science Quarterly, 47(4), 676-706.

Birkinshaw, J. - Gupta, K. (2013): Clarifying the Distinctive Contribution of Ambidexterity to the Field of Organization Studies. Academy of Management Perspectives, 27(4): p. 287-298.

Birkinshaw, J. and Gibson, C. (2004), Building Ambidexterity into an Organization, MIT Sloan Management Review, 45, pp. 46-55.

Birkinshaw, J. and Gibson, C. (2004b), Building an Ambidextrous Organization, Aim Research Working Paper Series, 003, pp. 1-18.

Blackburn, R. \& Cummings, L. L. (1982).Cognitions of work unit structure. Academy of Management Journal, 25, 836-854.

Blackburn, R., \& Cummings, L. L. 1982.Cognitions of work unit structure.Academy of Management Journal, 25(4): 836-854.

Brown, J. S., \&Duguid, P. (1991). Organizational learning and communities of practice: Toward a unified view of working, learning, and innovation. Organization Science, 2(1), 40-57.

Buluc, B. (2008). The Relationship Between Organizational Health and Organizational Citizenship Behaviors in Secondary Schools. Turkish Educational Sciances Journal, 6(4), 571.

Burns, L. R., D. R. Wholey. (1993). Adoption and abandonment of matrix management programs: Effects of organizational Characteristics and interorganizational networks. Academy of Management Journal. 36(1) 106-138.

Burns, T. - Stalker, G. M. (1961): The management of innovation.

Burton, M. Diane, O’Reilly, Charles A. and Bidwell Matthew. Management systems for exploration and exploitation: The micro-foundations of organizational ambidexterity. Paper presented at the annual meetings of the Academy of Management, Boston, August, 2012. 
Canova, S., Cortinovis, D. L. \&Ambrogi, F. (2017).How to describe bivariate data. Journal of Thoracic Disease, 9(6), 1741-1743.

Cao, Q., Gedajlovic, E., \& Zhang, H. (2009). Unpacking organizational ambidexterity: Dimensions, contingencies, andsynergisticeffects.OrganizationScience, 20(4), 781796.

Caspin-wagner, keren, Ellis, Shmuel and tishler, Asher. 2012. Balancing exploration and exploitation for firm's superior performance: the role of the environment. Paper presented at the annual meetings of the Academy of management.

Chandrasekaran, A., Linderman, K., \& Schroeder, R. (2012)."Antecedents to ambidexterity competency in high technology organizations". Journal of operations management, vol. 30, issue $1 / 2$, pp. 134-151.

Chermack, T. J., (2007). Disciplined imagination: Building scenarios and building theories. Futures, 39(1), 1-15.

Christophe, J. N. \& François-Charles, W. (2009).Gender differences in pay in African manufacturing firms. HAL, Working Paper No. 00421227.

Christophe, J. N. \& François-Charles, W. (2009).Gender differences in pay in African manufacturing firms. HAL, Working Paper No. 00421227.

Clark-Carter, D. (2010). Quantitative psychological research: the complete student's companion ( $3^{\text {rd }}$ ed.). Hove: Psychology Press.

Cronbach, L. J. \&Meehl, P. E. (1955). Construct validity in psychological tests. Psychological Bulletin, 52(4), 281-302.

Cohen, W. M., \&Levinthal, D. A. (1989). Innovation and learning: The two faces of R \& D. The Economic Journal, 99(397), 569-596.

Cooper (1994). “The Cost of Healthy Work Organizations” in C. L. Cooper and S. Williams. Creating Healthy Work Organizations, chichester, John Wiley.

Crossan M. M. and Apaydin, M. (2010). A multi-dimensional framework of organizational innovation: A systematic review of the literature, Journal of Management Studies, 47 (6): 1154-1191.

Crossan, M. M., Lane, H. W., \& White, R. E. (1999). An organizational learning framework: From intuition to institution. Academy of Management Review 24(2), 522-537.

Crossan, M., Vera, D., and Nanjad, L. (2008).Transcedent Leadership: Strategic Leadership in Dynamic Environments. Leadership Quaterly, 19: 569-581. 
Damanpour, F. 1991. Organizational innovation: A metal- analysis of effects of determinants and moderators. Academy of management Journal, 34: 555-590.

Danneels, E. 2002.The dynamics of product innovation and firm competences. Strategic Management Journal, 23, 1095-1121.

Dixon, N. M. (1992). Organizational learning: A review of the literature with implications for HRD professionals. Human Resource Development Quarterly, 3(1), 29-49.

Doz, Yves, Christopher Barlett, and C. K. Prahalad (1981). "Global Competitive Pressures And Host Country Demands: Managing Tensions in Multinational Corporations," California Management Review 23 (3): 63-74.

Doz, Yves, Christopher Bartlett, and C. K. Prahalad (1981). "Global Competitive Pressures vs. Host country Demands: Managing Tension in Multinational corporation," California management Review 23 (3): 63-74.

Drazin R and Van de Ven AH (1985). Alternative forms of fit in contingency theory. Administrative Science Quarterly, 30.

Drew, W. \& Robert, R. (2003). Quantifying construct validity: Two simple measures. Journal of Personality and Social Psychology, 84(3), 608-618.

E. W. Morrison, \& R. J. Bies, (1991). Impression Management in the feedback-seeking process: A literature review and research Agenda. Academy of Management Review. Vol. 16(3), 522-541.

Easterby Smith, M. (1997). Disciplines of organizational learning: contributions and critiques. Human Relations, 50(9), 1085-1113.

Ebben, J. J., \&Johnson, A. C. 2005.Efficiency, flexibility, or both?Evidence linking strategy to performance in small firms. Strategic Management Journal, 26, 1249-1259.

Eccles, RG and Crane DB (1988) Doing Deals: Investment banks at work. Harvard Business School Press, Boston.

Eisenhardt, K. M., \& Brown, S. L. (1998).Competing on the edge: Strategy as structured chaos. Long Range Planning, 31(5), 786-789.

Eisenhardt, K. M., \& Martin, J. A. (2000). Dynamic capabilities: What are they? Strategic Management Journal, 21 (10-11), 1105-1121.

Ettlie, J. E., Bridges, W. P., \& O’Keefe, R. D. (1984). Organization strategy and structural differences for radical versus incremental innovation. Management Science, 30(6), 682-695. doi: 10.1287/mnsc.30.6.682 
Fincham, J. E. (2008). Response rates and responsiveness for surveys, standards, and the journal.American Journal of Pharmaceutical Education, 72 (2), 1-3.

Fornell, C. \&Larcker, D. G. (1981).Evaluating structural equation models with unobservable variables and measurement error.Journal of Marketing Research, 18(1), 39-50.

Geerts, A. Blindenbach-Driessen and F. Gemmel 2010.Achieving a balance between exploration and exploitation in service firms.A longitudinal study. Academy of management proceedings 2010(1): 1-6. Google scholar, crossref.

Geerts, A., Blindenbach-Driessen, F., \&Gemmel, P. (2010).Achieving a balance between exploration and exploitation in service firms: A longitudinal study. Paper presented at the annual meetings of the Academy of Management.

Geerts, Annalies, Blindenbach-Driessen, Floortje and Gemmel, Paul (2010).Achieving a balance between exploration and exploitation in service firms: A Longitudinal study. A paper presented at the Annual meetings of the Academy of Management.

Ghemawat, P. - Ricarti Costa, J. (1993): The organizational tension between static and dynamic efficiency. Strategic Management Journal, (14): p. 59-73. Duncan, R. B. (1976): The ambidextrous organization: Designing dual structures for innovation. in: R. H. Kilmann - L.R. Pondy - D. Slevin (eds.): The management of organization design: Strategies and implementation. New York: North Holland: p. 167-188.

Ghoshal S and Nohria N (1989) internal differentiation within ultinationalcorporations.Strategic Management Journal, 10.

Gibson DG, et al. (2004). Diminished S-Phase cyclin-dependent kinase functions elicits vital Rad53-dependent checkpoint responses in saccharomyces cerevisiae. Moll Cell Biol 24(23):10208-22

Gibson, C. B. and Birkinshaw, J. (2004), The Antecedents, Consequences, and Mediating Role of Organizational Ambidexterity, Academy of Management Journal, 47, pp. 209-226.

Goosen, M. C., Bazzazian, N., \& Phelps, C. (2012). Consistently capricious: The performance effects of simultaneous and sequential ambidexterity. Paper presented at the annual meetings of the Academy of Management.

Goosen, Martin C., Bazzazian, Navid and Phelps, Corey (2012).Consistently capricious. The performance effects of simultaneous and sequential ambidexterity. Paper presented at the annual meetings of the Academy of Management.

Grant, R. M. (1996). Prospering in Dynamically-competitive Environments: Organizational Capability as Knowledge Integration. Organizational Science, 7(4), 375-387.

Greve, H. R. (2007). Exploration and exploitation in product innovation. Industrial and Corporate Change, 16(5), 945-975. doi: 10.1093/icc/dtm013 
Gupta, A. K. - Smith, K. G. - Shalley, C. E. (2006): The interplay between exploration and exploitation. Academy of Management Journal, 49(4): p. 693-706.

Gupta, A. K., Smith, K. G \&Shalley C. E. (2006).The Interplay between exploration and exploitation. Academy of Management Journal, 49: 693-706.

Gibson, J. L. \& Klein, S. M. (1970). Employee attitudes as a function of age and length of service: A reconceptualization. The Academy of Management Journal, 13(4), 411425.

Gibson, J. L. \& Klein, S. M. (1970).Employee attitudes as a function of age and length of service: A reconceptualization. The Academy of Management Journal, 13(4), 411425.

Gravetter, F. J., \&Wallnau, L. B. (2000).Statistics for the behavioral sciences ( $5^{\text {th }}$ edn).Belmont, CA: Wadsworth.

Hair, J. F., Jr., Anderson, R. E., Tatham, R. L. \& Black, W. C. (1998). Multivariate data analysis $\left(5^{\text {th }} \mathrm{ed}\right)$. Englewood Cliffs, NJ: Prentice Hall.

Han, M. and Celly, N. (2008), Strategic Ambidexterity and Performance in International New Ventures, Canadian Journal of Administrative Sciences, 25, pp. 335-349.

Hatch M. J., (1993). "The dynamics of organizational culture”. Academic Of Management Review, Vol. 18, pp. 657-93.

Hatch, M. J. (1997). Organization Theory: Modern Symbolic and Postmodern Perspectives. New York: Oxford University Press Inc.

Hatch, M.J., \& Cunliffe, A.L. (2006).Organisation Theory modern, symbolic and postmodern perspective. Oxford University Press; New York.

He, Z. L. and Wong, P. K. (2004), Exploration vs. Exploitation: An Empirical Test of the Ambidexterity Hypothesis, Organization Science, 15, pp. 481-494.

Hernandez-Esparllardo, M., Sanchez-Perez, M., and Segovia-Lopez.C. (2011). Exploitationand- Exploration-based-innovation: The role of knowledge in inter-firms relationships with distributions. Technovations, 31(5-6), 203-215.

Holmqvist, M. (2009). Comparing the organization: A new prescription for the learning organization? Management Learning, 40(3), 275-287.

Hoy, W. K., \&Fieldman, J. A., (1987). Organizational Health: The Concept and its measure. Journal of Research and Development in Education, 20, 20-38.

Huber, G. (1991). Organizational learning: the contributing processes and the literatures. Organization Science, (2)1, 88-115. 
Huber, G. P., \& Lewis, K. (2010). Cross understanding: Implications for group cognition and performance. Academy of Management Review, 35(1), 6-26.

Introduction: Social cognition in organizations. In H. P. Sims \& D. A. Gioia (Eds.), The thinking organization: The dynamics of organizational social cognition. San Francisco, CA: Jossey-Bass.

Ireland, R. D., Hitt, M. A., \&Sirmon, D. G. (2003). A model of Strategic Entrepreneurship: The construct and its dimensions. Journal of Management, 29: 963-989.

Jacobsen, D.G. \&Thorsvik, J. (2002) Hurmodernaorganisationerfungerar.Studentliteratur, Lund.

Jansen, J. (2005), Ambidextrous Organizations: A Multiple-Level Study of Absorptive Capacity, Exploratory and Exploitative Innovation and Performance, Unpublished Dissertation, ERIM https:// ep.eur.nl/handle/1765/6774 .

Jansen, J. J. P., Van den Bosch, F. A. J. and Volberda, H. W. (2005), Exploratory Innovation, Exploitative Innovation, and Ambidexterity: The Impact of Environmental and Organizational Antecedents, Schmalenbach Business Review, 57, pp. 351-363.

Jansen, J. J.P. 2006. Ambidextrous organizations.A multiple-level study of Absorptive capacity, Explorative and Explorative innovation, and performance.Ph. D. Thesis Erasmus Universiteit Rotterdam.

Jansen,J.J.,vandenBosch,F.A.,\&Volberda,H.W.(2006). Exploratory innovation, exploitative innovation, and performance: Effects of organizational antecedents and environmental moderators. Management Science, 52(11), 1661-1674.

Joe Tidd and Kuo-Nan Hsieh (2013). Open Service Innovation: The influences of Projects Novelty. Open Innovation Research Management and Practice: pp.159-185.

Junni, P., Sarala M. Rikka, Taras, Vas and Tarba, ShlomoYedida. (2013). Organizational ambidexterity and performance: A meta-analysis. Academy of Management Perspectives, 27(4) 299-312.

Karaguzel O.T., Zhang R., \& Liam K. P. "Integrated Simulation Based Design Optimization of Office Building Envelopes for the Minimization of Life Cycle Cost". The Second International Conference on Building Energy and Environment(COBEE 2012). Boulder, CO, U.S. August, 2012.

Katila, R., \&Ahuja, G. (2002). Something old, something new: A longitudinal study of search behavior and new product introduction. Academy of Management Journal, 45.

Katila, R., \&Ahuja, G. (2002). Something old, something new: A longitudinal study of search behavior and new product introduction. Academy of Management Journal, 45(6), 1183-1194. 
Langan-Fox, J., Anglim, J., \& Wilson, J. R. (2004). Mental models, team mental models, and performance: Process, development, and future directions. Human Factors and Ergonomics in Manufacturing, 14(4), 331-352.

Laplume, A. O. - Dass, P. (2012): Exploration and exploitation for various stages of firm growth through diversification. Paper presented at the annual meetings of the Academy of Management, Boston, August

Lawrence P.R and Lorsch J.W (1967) 'Organisation and Environment: Managing Differentiation and Integration ', Boston, Division of Research, Graduate School of Business Administration, Harvard University.

Levinthal, D. - March, J. (1993): Myopia of learning. Strategic Management Journal, (14): p. 95-112.

Li, Y., Vanhaverbeke, W., \&Schoenmakers, W. (2008). Exploration and exploitation in innovation: reframing the interpretation. Creativity and Innovation Management, 17(2), 107-126. doi: 10.1111/j.1467-8691.2008.00477.x

Liao, T. F. 2004. Comparing social groups: Wald statistics for testing equality among multiple logit models. International Journal of comparative sociology, 45: 3-16.

Lorsch, J. W. (1976). Contingency theory and organization design: A personal odyssey. In: R. H Kilmann, L. R. Pondy, \& D. P. Slevin (Eds.), The management of organization design,(pp. 141-169). New York: Elsevier North-Holland, Inc.

Lovas, B and Ghoshal, S. (2000). Strategy as Guided Evolution.Strategic Management Journal, 21, 875-96.

Lubatkin, M. H., Pimpek, Z., Ling, Y. and Veiga, J. F. (2006), Ambidexterity and Performance in Small- to Medium-Sized Firms: The Pivotal Role of Top Management Team Behavioral Integration, Journal of Management, 32, pp. 646-672.

Lumpkin, G. T., \&Dess G. G. (1996). Clarifying the entrepreneurial orientation construct and linking it to performance. Acedemy of Management Review, 21(1), 135-172.

March, G. James, (1991), Exploration and Exploitation in Organizational Learning, Organization Science, 2,pp.78-87.

Markides, C, and charitou, C. D. 2004.competing with dual business models: a contingency approach. Academy of management Executive, 18: 22-36.

Marquardt, M. J. (1999). Action learning in action: Transforming problems and people for world-class organizational learning. Palo Alto, CA: Davies-Black Publishing. 
Mclver, J. P., \& Carmines, E. G.(1981). Unidimensional scaling. Thousand Oaks, CA: Sage.

McGrath, R. 2001. Exploratory learning, innovative capacity, and managerial oversight. Academy of Management Journal, 44, 118-1.

Mehrabi, J., Gharakhani, D., Jalalifar, S., \& Rahmati, H. (2012).Barriers to Green Supply Chain management in the petrochemical sector. Life Science Journal, 9(4), 34383442.

Miles, M. B. (1969). Planned change and organizational health: Figure and ground. In F.D. Carver \& T.J. Sergiovanni (Eds), Organizations and Human Behavior (pp. 375-391). New York McGraw Hill.

Mintzberg, H. (1983). Designing effective Organisations.Prentice Hall, Inc. New Jersey.

Mintzberg, H. (1983). Power in and around organization. Englewood Cliffs, NJ: PrenticeHall.

Mukalula, PM (1996) Structural adjustment for a competitive environment: Survival strategies for medium sized organisation firms in Zambia .International Symposium for the Organisation and Management of Organisation, Spon, London.

Narver, J. C. \& Slater, S. F. (1995).“Market Orientation and Learning Organization”. Journal of Marketing, 59 (3): 63-74.

Niazi, M. \&Yazdekhasti, A. (2010).Organizational Health, Sokhanvaran Publishers $1^{\text {st }}$ impression.

Nelson R.R. \& Winter S.G. (1982). The Schumpeterian Tradeoff Revisited. The American Economic'

Nordman, C. J. \& Wolff, F. C. (2010).Gender differences in pay in African manufacturing firms. In: Gender disparities in Africa's labor market. Washington, D.C, United States. World Bank, Pp. 155-191.

O'Reilly, C. A. - Tushman, M. L. (2004): The ambidextrous organization. Harvard Business Review, (82): p. 74-81.

O'Reilly, C. A. - Tushman, M. L. (2013): Organizational Ambidexterity: Past, Present, and Future. The Academy of Management Perspectives, 27(4): p. 324-338.

Pisano, G. P. (1994). Knowledge integration and the locus of learning: An empirical analysis of process development.

Polit, D. F. \& Beck, C. T. (2012).Nursing research: Generating and assessing evidence for nursing practice $\left(9^{\text {th }}\right.$ ed.). Philadelphia, USA: WoltersKlower Health, Lippincott Williams \& Wilkins.

Porter, M. E. (1980). Competitive strategy: Techniques for analyzing industries and competitors. New York: Free Press. 
Journal DOI: www.doi.org/10.46654/RJMP

Porter, M. E. 1996. Wettbewerbsvorteile: spitzenleistungenerreichenundbehaupten. Frankfurt: campus.

Ppoadiuk, S. \&choo C. W. (2006). Innovation \& knowledge creation: How are these concepts related? International journal of information management, 26 (4), 302-312.

Prahalad,C.K.,\&Hamel,G.1990.Thecorecompetencies thecorporation.HarvardBusinessReview,68(3): 79-90.

Prieto, I. M. Revilla, E. \& Rodriguez-prado, B. (2009).Managing the knowledge paradox in product development.Journal of knowledge management, 13, 147-45.

Raisch, S. and Birkinshaw, J. (2008), Organizational Ambidexterity: Antecedents, Outcomes, and Moderators, Journal of Management, 34, pp. 375-409.

Raisch, Sebastian, Birkinshaw, Julian, Probst, Gilbert and Tushman, Micheal L. (2009). Organizational ambidexterity: Balancing exploitation and exploration for sustained performance. Organization Science, 20: 685-695.

Raish, S. (2008).Balanced Structures: Designing organizations for profitable growth.Long Range planning 41(5) 483-508.

Reading, MA: Addison Wesley Publishing Company.

Robbins S. P. (1990), Organization theory, Englewoods Cliffs, Prentice Hall.

Rotemberg, J. J. \& G. Saloner (2000)."Visionaries, Managers, and Strategic Direction", RAND Journal of Economics 31: 693-716.

Rotemberg, J. J. And Saloner, G. "Leadership Style and Incentives".Management Science Vol. 39(1993), pp. 1299-1318.

Rumsey. D. J. (2019). How to Interpret a Scatterplot.https://www.dummies.com/education/math/statistics/how-to-interpret-ascatterplot/

Sekaran, U. (2003). Research methods for business $\left(4^{\text {th }}\right.$ ed.). Hoboken, NJ: John $\quad$ Wiley $\quad \&$ Sons.

Shapiro, S. L., Schwartz, G. E., \& Bonner G. (1998). Effects of mindfulness-based stress reduction on medical and premedical students. Journal of Behavioral Medicine, 21: 581-599

Sidhu JS, Volberda HW, Commandeur HR. 2004. Exploring Exploration Orientation and Its Determinants: Some Empirical Evidence. Journal of Management Studies 41(6): 913932 
Siren, C. A., Kohtamaki, M., \&Kuckertz, A. (2012). Exploration and Exploitation Strategies, Profit Performance, and the Mediating role of strategic learning: Escaping the Exploitation of trap. Strategic Entrepreneurship Journal, 6(1), 18-41.

Sitkin, S. B., \& Pablo, A. L., (1992).Reconceptualizing the determinants of risk behavior. Academy of Management Review, 17(1), 9-38.

Slater, S. F., \&Narver, J. C. (1995).Market orientation and the learning organization. Journal of Marketing, 59(3), 63-74. doi: 10.2307/1252120.

Smith, W. - Tushman, M. L. (2005): Managing strategic contradictions: A top management model for managing innovation streams. Organization Science, 16(5): p. 522-536.

Sossay, C. A., Hyland, P. W. \&Ferrer, M. (2008). Supply chain collaboration: Capabilities for continuous innovation. Supply chain management-an international journal, 13(2), pp. 160-169.

Sunkuk K (1997) Organisation and managerial environment of the Korean organisation', Organisation Management and Economics, 15, 409-419.

Szulanski, G. (2003). Sticky knowledge.Barriers to knowing in the firm. Thousand Oaks, CA: Sage.

Tavakol, M., \&Dennick, R. (2011). Making sense of Cronbach's alpha. International Journal of Medical Education, 2, 53-55.

T. M. Amabile, "A Model of Creativity and Innovation in organizations," B. Staw and L. L. Cummings, eds., Research in organizational behavior, vol. 10 (Greenwich, CT: JAI Press, 1988).

Taylor, Alva HelfatCostance E. (2009). Organizational linkages for surviving technological change: Complementary assets, middle management and ambidexterity. Organization Science, 20: 718-739.

Teece, D. J., Pisano, G., \&Shuen, A. (1997). Dynamic capabilities and strategic management. Strategic Management Journal, 18(7), 509-533).

Tempelaar, M. P., \& Van De Vrande, V. (2012).Dynamism, munificence, internal and external exploration-exploitation and their performance effects. Paper presented at the annual meetings of the academy of management.

Tidd, J. and J. Bessant (2013). Managing Innovation: Integrating technological, market and organizational change. Chichester, john Wiley and Sons.

Tran and Tidd (2013).Effects of Organizational Structures and Learning Organization on Job Embeddedness and Individual Adaptive Performance.

Tran T (2008). A conceptual model of learning culture and innovation schema. Int. Bus. J., 18(3): 287-299. 
Tushman, M. L. and O'Reilly, C. A. (1996), Ambidextrous Organizations: Managing Evolutionary and Revolutionary Change, California Management Review, 38, pp. 830 .

Tushman, M., Smith, W. K., Wood, R. C., Westerman, G., \& O’Reilly, C. (2010).Organizational designs and innovation streams. Industrial and Corporate Change, 19(5), 1331-1366. doi: 10.1093/icc/dtq040.

Tushman, Micheal L. and O'Reilly, Charles A. (1996). The ambidextrous organizations: Managing evolutionary and revolutionary change. California Management Review, 38: $1-23$.

Tutar, H. \&Yilmaz, K. M. (2010).Geneliletisimkavramlarvemodellar [General Communication concepts and Models]. Ankara: Seckin Yayincilik.

Uotila, J., Maula, M., Keil, T., \& Zahra, S. A. (2009).Exploration, exploitation, and financial performance: Analysis of S\&P 500 corporations. Strategic Management Journal, 30(2), 221-231.

Uotila, Juha, Maula, Markku and Keil, Thomas and Zhara, Shaker A. 2008. Exploration, exploitation and firm performance: An analysis of S\&P 500 corporations. Strategic Management Journal, 30: 221-231.

Venkatraman V, Payne JW, Bettman JR, Luce MF, Huettal SA. Separate neural mechanisms underlie choices and strategic preferences in risky decision making. Neuron 2009; 62: 593-602. (PMC free article) (PubMed)

Voss, G. B. Sirdeshmukh, D. \&Voss, Z. G. (2008), the effects of slack resources and environmental threat on product exploration and exploitation. Academy of management journal, 51, 147-164.

Wang, Q., \& von Tunzelmann, N. (2000). Complexity and the functions of the firm: Breadth and depth. Research Policy, 29(7-8), 805-818.

Weick, K. E. (1991). The nontraditional quality of organizational learning. Organization Science, 2(1), 116-124.

West MA, Borrill CS, Dawson JF, Scully J, Carter M, Anelay S, Patterson MG, Waring J. (2002).'The link between the management of employees and patient mortality in acute hospitals'. International Journal of Human Resource Management, vol. 13, pp 12991310.

West, M. A., and Farr, J. L., (1990).Innovation at work.In M. A. West and J. L. Farr (Eds.). Innovation and creativity at work (pp. 03-13) New York: John Wiley and sons.

Winter, S.G.(2003).Understanding dynamic capabilities. Strategic Management Journal, 24(10), 991-995.

Yu, G.J. \& O. M. Khessina.(2012). "The role of Exploration in Firm survival in the Worldwide Optical Library Market, 1983-1999." Presented at 2012 Meeting of 
Journal DOI: www.doi.org/10.46654/RJMP

Article DOI: www.doi.org/10.46654/RJMP.14033

Academy of Management Meeting, Technology and Innovation Division, August, Boston, MA.

Zhang Y. et al. (2007). The role of autophagy in mitochondria maintenance: Characterization of mitochondrial functions in autophagy-deficient S. cerevisiae strains. Autophagy 3(4):337-46.

Zikmund, W. G., Babin, B. J., Carr, J. C. \& Griffin, M. (2010).Business research methods ( $8^{\text {th }}$ ed.). Mason, HO: Cengage Learning. 